\title{
Error-producing conditions in nursing staff work
}

\author{
Condições produtoras do erro no trabalho em enfermagem \\ Condiciones productoras del error en el trabajo de enfermería
}

\section{Handerson Silva-Santos', Tatiane Araújo-dos-Santos', Angélica Santos Alves', Maria Navegantes da Silva', Heloniza Oliveira Gonçalves Costa', Cristina Maria Meira de Melo' \\ ' Universidade Federal da Bahia, Nursing School. Salvador, Bahia, Brazil.}

\section{How to cite this article:}

Silva-Santos H, Araújo-dos-Santos T, Alves AS, Silva MN, Costa HOG, Melo CMM. Error-producing conditions in nursing staff work. Rev Bras Enferm [Internet]. 2018;71(4):1858-64. DOI: http://dx.doi.org/10.1590/0034-7167-2017-0192

\author{
Submission: 03-30-2017 Approval: 07-18-2017
}

\begin{abstract}
Objective: To analyze the errors made by nursing staff workers who faced ethical-disciplinary actions. Method: Document, exploratory, quanti-qualitative research. The information was collected in 13 ethical-disciplinary actions of COREN BA, dated from 1995 to 2010, which had as object of complaint an error made by nursing staff workers. The quantitative data were analyzed using descriptive statistics and the qualitative data was analyzed using the Human Error Theory and Sociology of Work. Results: Nursing technicians and assistants held most actions. The health institution, through the nursing service coordination, was the predominant complainer and the most frequent shift was daytime. Final considerations: The errors made by nursing staff workers demonstrate that error-producing conditions are present in the context of their occurrence in all actions, and understaffing and intensity of work are the most recurrent circumstances. Descriptors: Nursing; Working Conditions; Work; Medical Errors; Patient Safety.
\end{abstract}

\section{RESUMO}

Objetivo: Analisar os erros cometidos por trabalhadoras da enfermagem alvo de processos ético-disciplinares. Método: Pesquisa documental, exploratória, quanti-qualitativa. As informações foram coletadas em 13 processos ético-disciplinares do COREn BA, no período 1995 a 2010, que tinham como objeto de denúncia erro cometido por trabalhadoras da enfermagem. Os dados quantitativos foram analisados com uso da estatística descritiva e a análise dos dados qualitativos utilizou-se a abordagem da Teoria do Erro Humano e da Sociologia do Trabalho. Resultados: As técnicas e auxiliares de enfermagem são as trabalhadoras mais denunciadas. A organização de saúde, por meio da coordenação do serviço de enfermagem, foi a maior denunciante e o turno de maior ocorrência foi diurno. Considerações finais: Os erros cometidos pelas trabalhadoras da enfermagem demonstram que condições produtoras do erro estão presentes no contexto de sua ocorrência em todos os processos, sendo o subdimensionamento e a intensidade do trabalho as circunstâncias mais recorrentes.

Descritores: Enfermagem; Condições de Trabalho; Trabalho; Erro Médico; Segurança do Paciente.

\section{RESUMEN}

Objetivo: Analizar los errores cometidos por trabajadoras de enfermería, objeto de procesos ético-disciplinares. Método: Investigación documental, exploratoria, cuantitativa-cualitativa. Se recogieron las informaciones de 13 procesos ético-disciplinarios del COREn (Consejo Regional de Enfermería) de Bahía, durante el período comprendido entre 1995 y 2010, que tenían como objetivo denunciar errores cometidos por trabajadoras de enfermería. Los datos cuantitativos se analizaron mediante estadística descriptiva y en el análisis de los datos cualitativos se utilizó el abordaje de la Teoría del Error Humano y de la Sociología del Trabajo. Resultados: Las técnicas y auxiliares de enfermería son las trabajadoras más denunciadas. La principal denunciante fue la organización de la salud, a través de la coordinación del servicio de enfermería y el turno con más incidentes, el diurno. Consideraciones finales: Los errores cometidos por las trabajadoras de enfermería demuestran que las condiciones productoras de dichos errores están presentes en el contexto de todos los procesos, siendo el sub-dimensionamiento y la intensidad del trabajo, las circunstancias más recurrentes.

Descriptores: Enfermería; Condiciones de Trabajo; Trabajo; Error Médico; Seguridad del Paciente. 


\section{INTRODUCTION}

Errors are unintentional acts intrinsic to human beings. They are a product of circumstances when an action planned does not reach the expected result ${ }^{(1)}$.

The number of errors that occur in health systems and affect users, causing deaths and increasing costs, motivated the World Health Organization (WHO) to launch, in October 2004, the World Alliance for Patient Safety, a project aimed at developing an international classification for patient safety ${ }^{(2)}$. The error-prevention strategies adopted by $\mathrm{WHO}$ were monitored in different countries, such as the United States, the United Kingdom and Brazil.

In the United States of America, it is estimated that 44,000 to 98,000 people die in hospitals each year, victims of preventable errors $^{(3)}$. In Brazil, the Superior Court of Justice (STJ) registered a $1,600 \%$ increase in medical errors lawsuits in the last 14 years, and death $(28.16 \%)$ was the most claimed reason ${ }^{(4)}$.

Errors related to nursing work reported at the Regional Nursing Council of São Paulo presented a 220\% increase between 2011 and $2012^{(5)}$.

The numbers reveal that error is a phenomenon that should be investigated and debated in health services. However, the work culture in these environments usually values perfection, competence and competition, despising and hiding errors, with a guilt culture and fear-based management ${ }^{(6)}$.

Thus, work errors should be examined, considering human flaws and mechanisms created as barriers to the occurrence of errors. It should be noted that these barriers express the vulnerability of complex systems such as hospitals.

In complex systems, there is an intrinsic contradiction between operational efficiency and security. In the context of health, the safety of the users and workers is constrained by economic and time issues, productivity, customer services and the public image of the organization ${ }^{(7)}$. In addition, there is also the stress caused by the heavy workload and rigorous hierarchical structure of the work process.

Errors, in the contemporary context, are related to precarious work conditions. In this scenario, errors should be seen as evidence of deeper problems in complex systems, such as health services. This should be considered when the health institution and the regulatory agency approach the worker who made an error.

From the perspective of the regulation of the nursing profession, error is understood as an ethical violation based on an action, omission or connivance that represents a disobedience of the recommendations in the code of professional ethics. Thus, actions taken with no intent to harm may involve risk or injury to the patient, and thus can be classified as negligence, malpractice or recklessness, always in an individual perspective( ${ }^{(8)}$.

In the approach adopted by the current model of professional regulation, an Ethics. Disciplinary. Procedures (EDP) in the Nursing Board punishes the nurse worker who makes an error. In this case, the power that punishes is responsible for the social construction that error should be contained by punishing the individual, acting only with an ethical-professional focus, and, at the same time, denying the social relations of the work environment ${ }^{(9)}$.

In this sense, this article aims to analyze the errors made by nursing staff workers who faced an ethical-disciplinary action.

\section{Human Error Theory: critical approach}

There are two ways of viewing the problem of human error: through the person approach or the system approach. Each has its model of error causation and each model gives rise to different philosophies of error management ${ }^{(10)}$.

In health services, the general tradition is the person approach. The countermeasures to error associated with the person approach appeal to people's sense of fear, and result in change of procedures (creation of new procedures or adaptation of existing ones), disciplinary measures, retraining and threats of disciplinary and ethical actions ${ }^{(10)}$.

Followers of this approach understand error as a moral phenomenon, assuming that bad things happen to bad people. From this perspective, they personify error, blaming and shaming the people involved. Thus, in addition to civil responsibility for the act, the weight of guilt is imposed on those who commit errors ${ }^{(10)}$.

The "old view of human error" or "bad apple theory"(7) is based on the existence of people of low or small reliability (bad apples) in safe systems. The author suggests that this approach is popular because it is a simple, easy and inexpensive way to deal with patient safety. In addition, this approach can maintain the public image of the institution, exempting it from any responsibility for the occurrence of the error and treating the worker as the only culprit.

From the causality of the "old view of human error" or "bad apple theory" error is the cause of failure or as failure itself $f^{(11)}$. Thus, to solve the problem, investigators should look for flaws in evaluation, judgment and decision-making(7).

On the other hand, from a system approach, accidents occur due to an interconnection between several factors and different spheres of the institution, not only due to a single individual ${ }^{(1)}$. In this sense, it is necessary to include safety measures to block the occurrence of error, considering the complex system as a whole. From this perspective, the paradigm of the individual approach to error can be questioned.

The occurrence of error, even if it is the result of an individual act, cannot be separated from the context in which it occurs. However, this is exactly what happens in a person approach: error is separated from its context and reaffirmed as an act in itself instead of a component in a process ${ }^{(11)}$.

Work and employment conditions can be indicated as errorproducing conditions. Error-producing conditions are aspects that affect both task performance and the potential to increase the probability of error when a specific task is performed in the presence of these conditions ${ }^{(6)}$.

Working conditions can be defined as

a set of variables that influence the activity, the work and the life of the worker. Some of these variables are related to ergonomic aspects, salary, autonomy and job satisfaction, as well as to job stability and work flexibility, which are characteristics of the changing world of work ${ }^{(12)}$.

Therefore, the occurrence of errors is not related only to the individual attitude of the worker. In the field of nursing, the working conditions provided by the employer, such as equipment and material, infrastructure, organization of the work process, salary, working hours, labor rights, staff sizing in assistance services, 
among others, influence not only work performance, but also the final result achieved ${ }^{(12)}$. Thus, health-related working conditions are determinant for the safety of the patient and the worker and for possible occurrence of errors.

\section{OBJECTIVE}

To analyze the errors made by nursing staff workers who faced ethical-disciplinary actions.

\section{METHOD}

\section{Ethical aspects}

This study is part of the research "Nursing errors and job insecurity", funded by the Research Support Foundation of the State of Bahia. The study was approved by the Research Ethics Committee of the Nursing School of the Federal University of Bahia.

\section{Design, setting and study period}

This study is characterized as document, exploratory and quanti-qualitative. The research setting was the archive of the Regional Nursing Board of Bahia (COREN BA). The period assessed covered the years 1990 to 2014 .

\section{Sample, inclusion and exclusion criteria}

The data source was ethical-disciplinary actions. Inclusion criteria were open, complete or filed actions in this Board between 1990 and 2014. The exclusion criteria were the administrative actions and those that did not have the occurrence of the error as a complaint. A total of 160 actions were identified. Of these, 13 were filed due to some type of error committed by nursing workers.

\section{Study protocol}

Data was collected between May 2015 and May 2016, using an instrument developed by researchers, with the following dimensions: 1. Identification of the action: number, opening and closing date, description of the object of the complaint, date and shift of the occurrence of the error, complainer; 2. Characteristics of the worker: professional category, gender, age; 3. Characteristics of the organization where the error occurred: legal nature of the institution, type of work (whether hospital or others), sector of the work where the error occurred; 4. Identification of infringed articles; 5. Decision of the plenary session of the Regional Board on the actions.

In the 13 cases, the errors recorded were in the medication process. A medication error is any type of flaw in the medication administration process ${ }^{(2)}$. The classification of the errors identified in the actions is based on the COREn BA article, no. 021/2013(13) , which establishes rules to ensure the correct administration of medication.

Thus, the types of errors identified in this study are as follows: (I) Incorrect medication: error resulting from changing prescribed medication; (II) Incorrect patient: error resulting from changing patient; (III) Incorrect action: error due to incorrect execution of the procedure; (IV) Incorrect route: error related to the change of the route of administration of the medication; $(V)$ Incorrect dose: error resulting from improper preparation of a drug, whether a superdosage or underdosage; (VI) Incorrect registration: error due to lack of registration after administration of the drug, incomplete registration or registration of a medication without its administration.

\section{Analysis of results and statistics}

Quantitative data were analyzed using descriptive statistics, with absolute frequencies. For the analysis of the qualitative data, the Human Error Theory approach and Sociology of Work were used. In the analysis of the actions, we sought to identify the following interconnections: the error committed, the error-producing conditions and the procedural evidence of the error-producing conditions.

\section{RESULTS}

The actions found in the investigation period were between the years 1995 and 2010, with the highest concentration of cases (03) in 2010.

The health institution, through the nursing service coordination, was the complainer in five of the 13 cases. As for the shift of the occurrence, day shifts (morning/afternoon) were the most cited (08 cases).

The characteristics of the workers who faced the actions are described in Table 1. It is worth noting that more than one worker can be denounced in a disciplinary action. Female nursing workers with no higher education were the most reported.

Regarding the nature of the institutions in the cases, six are public and seven are private. The hospital is the place mentioned in 10 cases, and the hospital unit in the most mentioned, with seven records.

In all ethical-disciplinary actions analyzed, medication error was the object of complaint, as can be observed in Table 2.

In Chart 1, we present the analysis of the actions through the Human Error theory.

Table 1 - Distribution of characteristics of the workers who faced ethical-disciplinary actions, according to professional category, gender and age group, Salvador, Bahia, Brazil, 2016

\begin{tabular}{lc}
\hline Characteristics of the workers & $\mathbf{n}$ \\
\hline Professional category & \\
Nurse & 04 \\
Nursing technician & 03 \\
Nursing assistant & 11 \\
Total & 18 \\
Gender & \\
Male & 0 \\
Female & 18 \\
Total & 18 \\
Age group & \\
20-30 & 4 \\
$31-40$ & 10 \\
41 and older & 3 \\
Total & 18 \\
\hline
\end{tabular}

Source: COREn BA files, 2016

Table 2 - Description of the errors and object of complaint in ethical actions, Salvador, Bahia, Brazil, 2016

\begin{tabular}{lc}
\hline Object of complaint & $\mathbf{n}$ \\
\hline Incorrect medication & 2 \\
Incorrect patient & 3 \\
Incorrect action & 2 \\
Incorrect route & 5 \\
Incorrect dosage & 1 \\
Total & 13 \\
\hline
\end{tabular}

Source: COREn BA files, 2016 
Chart 1 - Error Categories of analysis according to the Human Error Theory

\begin{tabular}{|c|c|c|}
\hline Error & $\begin{array}{l}\text { Error-producing } \\
\text { conditions }\end{array}$ & Evidence on the processes \\
\hline \multirow{4}{*}{$\begin{array}{l}\text { Incorrect } \\
\text { route }\end{array}$} & $\begin{array}{l}\text { Understaffing of workers } \\
\text { and intensity of work }\end{array}$ & $\begin{array}{l}\text { I was on duty and took over the four clinics and the CME, so I had around one hundred and } \\
\text { fifty patients. (Process } 4 \text { ) } \\
\text { I got confused at the time because I was administering medication on many patients and work- } \\
\text { ing alone. (Process } 4 \text { ) }\end{array}$ \\
\hline & $\begin{array}{l}\text { Lack of supervision of the } \\
\text { work process of nursing } \\
\text { technicians and assistants }\end{array}$ & $\begin{array}{l}\text { There is no direct and constant supervision over the nursing assistant in the outpatient clinic, } \\
\text { because there is no professional available for this. There are } 02 \text { [two] nurses, } 01 \text { [one] in charge } \\
\text { of the nursing consultation and the other in charge of drug manipulation. (Process 7) }\end{array}$ \\
\hline & Intensity of work & $\begin{array}{l}\text { Did anyone ask if I was okay to work that night? I decided to stay so that my night colleague } \\
\text { wouldn't work alone. (Process 1) }\end{array}$ \\
\hline & Labor rights issues & $\begin{array}{l}\text { [...] but she was overloaded because she was from Fapex [outsourced by the Research and } \\
\text { Extension Support Foundation of the Federal University of Bahia] and had no right to family } \\
\text { support [...]. (Process } 3 \text { ) }\end{array}$ \\
\hline \multirow{3}{*}{$\begin{array}{l}\text { Incorrect } \\
\text { patient }\end{array}$} & $\begin{array}{l}\text { Lack of material and } \\
\text { equipment }\end{array}$ & $\begin{array}{l}\text { [...] there is lack of materials, the equipment is not new, there is no protocol, we do not have } \\
\text { an emergency car, even though we requested one several times. (Process 2) }\end{array}$ \\
\hline & Intensity of work & $\begin{array}{l}\text { A hectic day, full of occurrences, tired mothers worried about their children, many attributions } \\
\text { as you already know [...]. (Process 10) }\end{array}$ \\
\hline & $\begin{array}{l}\text { Understaffing of workers } \\
\text { and intensity of work }\end{array}$ & $\begin{array}{l}\text { How many patients were scaled for each professional? There are about thirteen for each nurs- } \\
\text { ing technician, I believe that on average there are } 42 \text { or } 45 \text { beds. Many patients are severe } \\
\text { because the hospital serves the entire southwest region. They often have ICU indication, but } \\
\text { there is no bed available so they stay in the medical clinic waiting for the vacancy. (Process 11) }\end{array}$ \\
\hline \multirow{4}{*}{$\begin{array}{l}\text { Incorrect } \\
\text { medication }\end{array}$} & $\begin{array}{l}\text { Understaffing of workers } \\
\text { and intensity of work }\end{array}$ & $\begin{array}{l}\text { We questioned the presence of only } 02 \text { nursing assistants to assist } 13 \text { patients, plus the deliv- } \\
\text { ery room, the prompt care and inter-occurrences in the unit. (Process 12) }\end{array}$ \\
\hline & $\begin{array}{l}\text { Inadequate medication } \\
\text { storage }\end{array}$ & $\begin{array}{l}\text { In the refrigerator where you keep the medications are there specific compartments for anes- } \\
\text { thetics? No, it's a small refrigerator and the medications are in the refrigerator door and on the } \\
\text { shelves, including blood without separation. (Process 5) }\end{array}$ \\
\hline & Labor rights issues & $\begin{array}{l}\text { Are you entitled to rest during the shift? No. When the shift is calmer, which was not the case, we } \\
\text { take the mattresses from the cradle and put them on the floor and we take turns to rest. (Process 12) }\end{array}$ \\
\hline & Intensity of work & $\begin{array}{l}\text { We, nursing assistants, must leave our shift with all patients bathed, beddings changed, vital } \\
\text { signs checked, medications delivered, dressings done, as well as leave all the material used } \\
\text { already washed, dried and packed for sterilization. (Process 5) }\end{array}$ \\
\hline \multirow{2}{*}{$\begin{array}{l}\text { Incorrect } \\
\text { action }\end{array}$} & \multirow{2}{*}{$\begin{array}{l}\text { Understaffing of workers } \\
\text { and intensity of work }\end{array}$} & $\begin{array}{l}\text { And since there are no nurse in the institution in some periods, some procedures that are exclusive } \\
\text { to the nurse are performed by the nursing assistants and technicians. Also, some activities are ag- } \\
\text { gregated when some sectors such as laundry and pharmacy are not functioning. (Process 6) }\end{array}$ \\
\hline & & $\begin{array}{l}\text { A busy night shift, at that time I was responsible for pediatric patients and the outpatient } \\
\text { clinic from } 7 \text { p.m. to } 10 \text { p.m., and then I left the clinic to the next colleague, and continued } \\
\text { in pediatrics (Process } 8 \text { ) }\end{array}$ \\
\hline \multirow{2}{*}{$\begin{array}{l}\text { Incorrect } \\
\text { dosage }\end{array}$} & $\begin{array}{l}\text { Understaffing of workers } \\
\text { and intensity of work }\end{array}$ & $\begin{array}{l}\text { How many nurses work there? Only one nurse worked in two emergency units. The emer- } \\
\text { gency has a turnover of about } 700 \text { patients per day [...]. (Process 13) } \\
\text { Usually the shift in the hospital is quite busy. (Process 13) }\end{array}$ \\
\hline & $\begin{array}{l}\text { Lack of material and } \\
\text { equipment }\end{array}$ & $\begin{array}{l}\text { Do you think the hospital has the structure to follow up the oncology patient coming from } \\
\text { other institutions? No, there is a lack of physical structure, lack of training and lack of equip- } \\
\text { ment for personal protection. (Process 13) }\end{array}$ \\
\hline
\end{tabular}

\section{DISCUSSION}

Nursing technicians and assistants are the workers with most actions. This fact can be explained by the technical and social division of nursing stuff work, which is hierarchical in Brazil. Workers with no higher education take over tasks and technical assistance activities, while the nurse coordinates this process, which represents the dual care-management nature of their work ${ }^{(14)}$.

The technical and social division of nursing work favors the error, because it separates planning and execution: the nurses are responsible for the first activity and the nursing technicians and assistants for the second. The division between intellectual and manual labor would require an adequate number of nurses to supervise the work of the technicians and assistants. In addition, the work performed by these workers can be questioned, since it is contrary to what is determined in the law of professional practice ${ }^{(15)}$.

Among the cases, the health institutions, represented by the nursing coordination, stand out as complainers. This may be because users are unaware of the Nursing Board's role and that they could seek the Board to file the complaint without necessarily addressing the health institution. Therefore, the communication process between the Nursing Board and the society still needs to be improved. 
The free access of the patient or the person authorized by him/her to the information on his/her health condition is established in the Health Users' Rights Letter ${ }^{(16)}$. However, it is not uncommon for this process to be hampered by professionals or the institution ${ }^{(17-18)}$.

The person approach to error and the culture of fear ${ }^{(1)}$ fostered in health institutions allow us to infer that, when formalizing the complaint with the Board, organizations disclaim responsibility for the error committed, as they seek to maintain the image that they are working to solve the error, which is resolved with the punishment of the worker.

This type of approach to error is supported by the Code of Ethics of Nursing Professionals (CEPE), which regulates the person approach to error. This allows the worker to be punished without other mechanisms that address the institution co-responsibility, which can be seen in the legislation governing nursing work in the United States ${ }^{(19-20)}$ and in the UK National Health System ${ }^{(21)}$.

Workers interviewed in another study claim that errors in the medication process are often not reported due to fear of the punitive approach, which corresponds to $80.3 \%$ of the measures taken in institutions. Thus, in addition to civil responsibility for the act, the burden of guilt is imposed on professional who make an error, and the working conditions are not taken into account $^{(22)}$.

However, the error in the medication process is easily identifiable, given the reactions it can cause and because it involves several workers and steps, which allows for more failures and requires more control in the barriers for error protection. Patients admitted to hospitals are usually submitted to a drug therapy, and drug preparation and administration are the tasks most performed by nursing technicians and assistants. In addition, the hospital work process is controlled with well-structured operational protocols.

The data on Chart 1 demonstrate that error-producing conditions are related to precarious work conditions. This is a strategy used by employers based on the workers' insecurity and fear of losing the job, which makes them accept exploitation and poor working conditions ${ }^{(23)}$.

In all the cases, we identified understaffing and high intensity of the work, with accelerated rhythm and double shifts, as error-producing conditions. These two factors are related, because, by keeping a nursing staff below what is necessary for the execution of the assistance, the employer intensifies the work of those still in the institution, assigning multiple tasks and actions to the professional. As an example of the impact of work intensity and understaffing on patient safety, Aiken et al. ${ }^{(24)}$ state that each additional patient generates work overload for a nurse, increasing by $7 \%$ the probability of a patient dying when hospitalized.

The intensity of the work refers to the personal and group energy expended by the workers in their daily work ${ }^{(25)}$. We can observe in the actions that the workers, due to understaffing, are forced to assume multiple functions and tasks. The multifunctional and multipurpose worker is a characteristic of the Toyotist work organization model, which assumes the workers' flexibility and willingness to solve problems during their shift ${ }^{(26)}$. However, a greater intensity of work predisposes the worker to fatigue, distractions and lapses.

The accelerated work rhythm in the hospital environment causes physical and psychological distress, which interferes directly with the work performed ${ }^{(27)}$. The working conditions ${ }^{(12)}$ are composed of a set of variables that influence not only the work, but also the life of the worker. Thus, in the ethicaldisciplinary actions analyzed, we note that the performance of nursing work is compromised by the precarious working conditions offered by the employers, which are revealed as error-producing conditions.

\section{Limitations of the study}

A limitation of this study is the analysis of only nursing errors that were reported to COREn BA and resulted in an ethicaldisciplinary action. It is possible that, during the period covered by this study, other errors occurred in the health services, but not all of them became objects of complaint and, consequently, ethical-disciplinary actions.

\section{Contributions to the area of Nursing}

This research unravels the precarious conditions of nursing work, which are revealed as the cause of errors at work. Based on this study it is also possible to question the culture of fear in health institutions and its consequence in the face of error: the individual and punitive approach of the nursing worker, disregarding the context, the working conditions and the coresponsibility of the health institution.

\section{CONCLUSION}

The guilt for the error, as expected, is frequently imposed on nursing technicians and assistants, due to the place occupied by these workers in the technical and social division of labor. The errors found in the study refer only to the medication process.

The health institution is highlighted as complainer, which reveals, on the one hand, the low access to information and sanitary awareness among users and, on the other hand, the punitive and individualized approach to error on the part of the institution.

The errors made by nursing workers who faced ethicaldisciplinary actions are originated in a structural phenomenon (working conditions) and not a moral phenomenon (individual flaw). Error-producing conditions, related to the precarious work conditions, are present in the context of error in all the cases, and understaffing and intensity of work are the most recurrent error-producing conditions. This finding contributes to demystify the assumption that the worker makes the error alone: the health institution, while maintaining error-producing conditions, is also responsible for the occurrence of the error.

\section{FUNDING}

Research Support Foundation of the State of Bahia (Fapesb).

\section{ACKNOWLEDGEMENTS}

To the Regional Nursing Board of Bahia. 


\section{REFERENCES}

1. Reason J. El error humano. Madrid: Modus Laborandi; 2009.

2. World Health Organization-WHO. The Conceptual Framework for the International Classification for Patient Safety[Internet]. 2009[cited 2016 Nov 05]. Available from: http://www.who.int/patientsafety/taxonomy/icps_full_report.pdf

3. US. Institute of Medicine. Committee on Quality of Health Care in America. To err is human: building a safer health system[Internet]. National Academy of Science. 1999[cited 2016 Nov 20]. Available from: https://www.ncbi.nlm.nih.gov/pubmed/25077248

4. Ferraz A. Erros médicos crescem $1.600 \%$ em 10 anos: o aumento na demanda é a principal causa, mas a falta de qualificação também é um risco. Tribuna da Bahia[Internet]. 2015 Apr 08;[cited 2015 May 25]. Available from: http://www.tribunadabahia. com.br/2015/04/08/erros-medicos-crescem-1600-em-10-anos

5. Lenharo M. Denúncias contra profissionais de enfermagem crescem 220\% em 2 anos. O Estado de São Paulo[Internet]. 2013 Feb 03[cited 2016 Nov 01]. Available from: http://www.estadao.com.br/noticias/geral,denuncias-contra-profissionais-de-enfermagem-crescem-220-em-2-anos-imp-,992311

6. Drews FA, Musters A, Samore MH. Error Producing Conditions in the Intensive Care Unit. In: Henriksen K, Battles JB, Keyes MA, Grady ML, (Eds.). Advances in Patient Safety: new directions and alternative approaches. 3th vol.: Performance and Tools[Internet]. Rockville (MD): Agency for Healthcare Research and Quality (US); 2008[cited 2016 Nov 01]. Available from: http://www.ncbi. nlm.nih.gov/books/NBK43691

7. Dekker S. The field guide to human error. Bedford, UK: Cranfield University Press; 2001. 112p.

8. Sidon LU, Barreto IS, Sousa OAF, Macedo F, Peixoto AD. Análise preliminar dos Processos Ético-Disciplinares transitados em julgado no Cofen (2005-2010): um ensaio para a pesquisa. Enferm Foco[Internet]. 2012[cited 2016 Dec 02];3(4):216-8. Available from: http://revista.portalcofen.gov.br/index.php/enfermagem/article/viewFile/388/179

9. Foucault M. Vigiar e punir: a história da violência nas prisões. Petrópolis, RJ: Vozes; 2015. 328p.

10. Reason J. El Human error: models and management. BMJ[Internet]. 2000[cited 2016 Aug 29];320(7237):768-70. Available from: https://www.ncbi.nlm.nih.gov/pmc/articles/PMC1117770/

11. Woods DD, Cook RI. Mistaking Error. In: Youngberg BJ. Patient Safety Handbook. Burlinton, MA: Jones and Bartlett Learning; 2013. p. $99-110$

12. Silva MC. Condições de trabalho da enfermeira nos hospitais do sistema único de saúde da Bahia[Dissertação]. Universidade Federal da Bahia. 2016. 100p.

13. Conselho Regional de Enfermagem da Bahia. Parecer $n^{\circ}$ 021/2013. Dosagem de Medicamentos como Responsabilidade do Enfermeiro. Salvador: COREn BA; 2013[cited 2016 Nov 05]. Available from: http://ba.corens.portalcofen.gov.br/parecer-corenba-0212013_8112.html

14. Melo CMM, Santos TA, Leal JAL. Processo de trabalho assistencial-gerencial da enfermeira. In: Vale EG, Peruzzo SA, Felli VEA. PROENF-Programa de Atualização em Enfermagem: Gestão: Ciclo 4. Sistema de Educação Continuada a Distância. Porto Alegre, RS: Artmed Panamericana; 2015. p.45-75.

15. Lei n. 7498de 25 de junho de 1986. Dispõe sobre a regulamentação do exercício da enfermagem, e dá outras providências. Diário Oficial da União[Internet]. 1986[cited 2016 Nov 01]. Available from: http://www.planalto.gov.br/ccivil_03/leis/L7498.htm

16. Carta dos direitos dos usuários da saúde. 3. ed. Brasília(DF): Ministério da Saúde; 2011.

17. Leite RAF, Brito ES, Silva LMC, Palha PF, Ventura CAA. Acesso à informação em saúde e cuidado integral: percepção de usuários de um serviço público. Interface[Internet]. 2014[cited 2016 Nov 01];18(51):661-71. Available from: http://dx.doi. org/10.1590/1807-57622013.0653

18. Bittencourt ALP, Quintana AM, Velho MTAC, Goldim JR, Wottrich LAF, Cherer EQ. A voz do paciente: por que ele se sente coagido? Psicol Estudo[Internet]. 2013[cited 2016 Nov 12];18(1):93-101. Available from: http://dx.doi.org/10.1590/S1413-73722013000100010

19. National Council of State Boards of Nursinng-NCSBN. Board and Regulation, Board Action[Internet]. 2016 [cited 2016 Sep 20]. Available from: https://www.ncsbn.org/673.htm

20. Ismail F, Clarke SP. Improving the Employer-Regulator Partnership: an analysis of employer engagement in discipline monitoring. J Nurs Regul[Internet]. 2014[cited 2016 Nov 05];5(3):19-23. Available from: http://journalofnursingregulation.com/article/ S2155-8256(15)30056-9/abstract

21. National Health Service[Internet]. Patient Safety Alerts. National Patient Safety Alerting System. England: NHS; $2014[\mathrm{cited} 2015$ Sep 20]. Available from: http://www.england.nhs.uk/patientsafety/psa/

22. Santos JC, Ceolim MF. latrogenia de enfermagem em pacientes idosos hospitalizados. Rev Esc Enferm USP[Internet]. 2009[cited 2016 Nov 01];43(4):810-17. Available from: http://www.scielo.br/pdf/reeusp/v43n4/a11v43n4.pdf

23. Druck G. A precarização social do trabalho no Brasil. In: Antunes R. Riqueza e miséria do trabalho no Brasil II. São Paulo (SP): Boitempo; 2013. p. 55-74.

24. Aiken LH, Clarke SP, Sloane DM, Sochalki J, Silber JH. Hospital nursing staffing and patient mortality, nurse burnout, and job 
dissatisfaction. JAMA[Internet]. 2002[cited 2016 Oct 10];288(16):1987-993. Available from: http://jamanetwork.com/journals/ jama/fullarticle/195438

25. Dal Rosso S, Cardoso ACM. Intensidade do trabalho: questões conceituais e metodológicas. Soc Estado[Internet]. 2015 [cited 2016 Aug 02];58(4):31-4. Available from: http://dx.doi.org/10.1590/S0102-69922015.00030003

26. Antunes R, Druck G. A terceirização como regra? Rev Trib Sup Trab[Internet]. 2013[cited 2016 Nov 01];79(4):214-31. Available from: https://juslaboris.tst.jus.br/bitstream/handle/1939/55995/011_antunes_druck.pdf? sequence $=1$ \&isAllowed =y

27. Gonçalves FGA, Sousa NVD, Pires AS, Santos DM, D'Oliveira CAFB, Ribeiro LV. Modelo neoliberal e suas implicações para a saúde do trabalhador de enfermagem. Rev Enferm UER][Internet]. 2014[cited 2016 Nov 05];22(4):519-25. Available from: http:// www.facenf.uerj.br/v22n4/v22n4a14.pdf 